\title{
PENGARUH POSISI DUDUK DAN BERDIRI TERHADAP TEKANAN DARAH SISTOLIK DAN DIASTOLIK PADA PEGAWAI NEGERI SIPILKABUPATEN MINAHASA UTARA
}

\author{
${ }^{1}$ Mercy Manembu \\ ${ }^{2}$ Jimmy Rumampuk \\ ${ }^{2}$ Vennetia R. Danes
}

\author{
${ }^{1}$ Kandidat Skripsi Bagian Fisika Kedokteran Universitas Sam Ratulangi Manado \\ ${ }^{2}$ Bagian Fisika Kedokteran Universitas Sam Ratulangi Manado \\ Email: mercy.manembu@yahoo.com
}

\begin{abstract}
Blood Pressure (BP) is the pressure of blood that is pumped by the heart against arterial wall. Blood Pressure is the pushing force for the blood which can circulate to the whole body to give fresh blood that contains oxygen and nutrients to body organs. This study aimed to obtain the blood pressure measurements of the North Minahasa Regency civil servants in two body positions, namely sitting position (SeP) and standing position (StP). This study was conducted in the period of June to July 2015 at the complex of the Mayor office of North Minahasa Regency in Airmadidi District. This was an observational analytical study with a cross sectional approach. Samples were determined with simple random sampling and the amount of samples was 42 people. The data were analyzed by using SPSS 20 with the Wilcoxon signed ranks test. The results showed that there was a significant difference between measurements of blood pressure during sitting position (SeP) and standing position (StP). The data showed that Systoloc BP SeP $=117.9841 \pm 12.5877 \mathrm{mmHg}$ vs Systolic StP $=124.7302 \pm 11.9546 \mathrm{mmHg}$, whereas Diastolic BP SeP $=79.2698 \pm 9.0656 \mathrm{mmHg}$ vs Diastolic StP $=87.5238 \pm 8.6639 \mathrm{mmHg}$. The Wilcoxon signed ranks test indicated that there was a significant difference between the two groups $(\mathrm{p}=0.000<\alpha=0.05)$. Coclusion: Body positions namely sitting position and standing position affected both systolic and diastolic blood pressure. Blood pressure in standing position showed a tendency to be higher than that of sitting position.

Keywords: systolic, diastolic, blood pressure, sitting position, standing position, civil servants
\end{abstract}

\begin{abstract}
Abstrak: Tekanan darah adalah tekanan dari darah yang dipompa oleh jantung terhadap dinding arteri. Tekanan darah merupakan kekuatan pendorong bagi darah agar dapat beredar ke seluruh tubuh untuk memberikan darah segar yang mengandung oksigen dan nutrisi ke organ-organ tubuh. Penelitian ini bertujuan untuk mengetahui hasil pengukuran tekanan darah antara posisi duduk dan posisi berdiri pada Pegawai Negeri Sipil (PNS) Pemerintah Kabupaten Minahasa Utara. Penelitian dilaksanakan di kompleks Kantor Bupati Minahasa Utara, Airmadidi pada bulan Juni-Juli 2015. Metode penelitian ini yaitu observasional analitik dengan pendekatan potong lintang. Sampel ditentukan secara simple random sampling yang berjumlah 42 orang. Data dianalisis menggunakan SPSS 20 dengan Wilcoxon Signed Ranks Test. Hasil penelitian menunjukkan terdapat perbedaan hasil pengukuran tekanan darah antara posisi duduk dan posisi berdiri. Tekanan darah sistolik antara posisi duduk vs posisi berdiri 117,9841 $\pm 12,5877 \mathrm{mmHg}$ vs $124,7302 \pm 11,9546$ mmHg dan tekanan darah diastolik antara posisi duduk vs posisi berdiri 79,2698 $\pm 9,0656 \mathrm{mmHg}$ vs $87,5238 \pm 8,6639 \mathrm{mmHg}$. Hasil Wilcoxon Signed Ranks Test menunjukkan bahwa terdapat perbedaan bermakna antara posisi duduk dan posisi berdiri dengan nilai $\mathrm{p}=0,000<\alpha=0,05$. Simpulan: Posisi badan yaitu posisi duduk dan berdiri pada saat dilakukan pengukuran tekanan darah memengaruhi hasil tekanan darah baik sistolik maupun diastolik. Pada posisi berdiri tekanan darah cenderung lebih tinggi dibanding pada posisi duduk.
\end{abstract}

Kata kunci: tekanan darah, posisi duduk, posisi berdiri 
Tekanan darah merupakan faktor yang dapat dipakai sebagai indikator untuk menilai sistem kardiovaskuler. Tekanan darah seseorang dipengaruhi oleh berbagai faktor di antaranya adalah perubahan posisi tubuh dan aktivitas fisik. Dengan mengamati serta mempelajari hasil pengaruh perubahan posisi tubuh dan aktivitas fisik terhadap tekanan darah, kita akan memperoleh sebagian gambaran mengenai sistem kardio vaskuler seseorang. ${ }^{1}$ Tekanan darah itu sendiri adalah tekanan yang dihasilkan oleh darah terhadap pembuluh darah. Tekanan darah ini dipengaruhi oleh volume darah dan elastisitas pembuluh darah. Peningkatan tekanan darah disebabkan peningkatan volume darah atau elastisitas pembuluh darah. Sebaliknya, penurunan volume darah akan menurunkan tekanan darah. ${ }^{2}$

Pada manusia, besar tekanan darah di dalam pembuluh darah dikenal dengan sebutan tekanan darah arteri rata-rata yang mana adalah gaya utama yang mendorong darah kearah jaringan. Tekanan ini harus diukur secara ketat dengan dua alasan. Pertama, tekanan tersebut harus cukup tinggi untuk menghasilkan gaya dorong yang cukup; tanpa tekanan ini, otak dan jaringan lain tidak akan menerima aliran yang adekuat seberapapun penyesuaian lokal mengenai resistensi arteriol ke organorgan tersebut yang dilakukan. Kedua, tekanan tidak boleh terlalu tinggi sehingga menimbulkan beban kerja tambahan bagi jantung dan meningkatkan resiko kerusakan pembuluh serta kemungkinan rupturnya pembuluh-pembuluh halus. ${ }^{3}$

Mekanisme-mekanisme yang melibatkan integrasi berbagai komponen sistem sirkulasi dan sistem tubuh lain penting untuk mengatur tekanan darah arteri ratarata. Dua penentu utama tekanan darah arteri rata-rata adalah curah jantung dan resistensi perifer total. Perubahan setiap faktor tersebut akan mengubah tekanan darah kecuali apabila terjadi perubahan kompensatorik pada variabel lain sehingga tekanan darah konstan. Aliran darah ke suatu jaringan bergantung pada gaya dorong berupa tekanan darah arteri rata-rata dan derajat vasokonstriksi arteriol-arteriol jaringan tersebut. Karena, tekanan arteri rata-rata bergantung pada curah jantung dan derajat vasokonstriksi arteriol, jika arteriol di salah satu jaringan berdilatasi, arteriol di jaringan lain akan mengalami konstriksi untuk mempertahan-kan tekanan darah arteri yang adekuat, sehingga darah mengalir tidak saja ke jaringan yang mengalami vasodilatasi tetapi juga ke otak, yang harus mendapatkan pasokan darah yang konstan. Dengan demikian variabel kardiovaskuler harus terus menerus diubah untuk mempertahankan tekanan darah yang konstan walaupun kebutuhan jaringan akan darah berubah-ubah. ${ }^{3}$.

Kecepatan aliran darah yang melalui seluruh sistem sirkulasi sama dengan kecepatan pompa darah oleh jantung yakni, sama dengan curah jantung. ${ }^{5}$ Isi sekuncup jantung dipengaruhi oleh tekanan pengisian (preload), kekuatan yang dihasilkan oleh otot jantung, dan tekanan yang harus dilawan oleh jantung saat memompa (afterload). Normalnya, afterload berhubungan dengan tekanan aorta untuk ventrikel kiri, dan tekanan arteri untuk ventrikel kanan. Afterload meningkat bila tekanan darah meningkat, atau bila terdapat stenosis (penyempitan) katup arteri keluar. Peningkatan afterload akan menurunkan curah jantung jika kekuatan jantung tidak meningkat. Baik laju denyut jantung maupun pembentukan kekuatan, diatur oleh sistem saraf otonom (SSO/autonomic nervous system, ANS). ${ }^{4}$

Jantung memompa darah secara kontinyu ke dalam aorta, sehingga tekanan rata-rata di aorta menjadi tinggi, rata-rata sekitar 100 mmHg. Demikian juga, karena pemompaan oleh jantung bersifat pulsatil, sebagai akibat pengosongan ritmik ventrikel kiri, tekanan arteri berganti-ganti antara nilai tekanan sistolik $120 \mathrm{mmHg}$ dan nilai tekanan diastolik $80 \mathrm{mmHg}^{4,5}$ Pada orang dewasa sehat, tekanan pada puncak setiap pulsasi, yang disebut tekanan sistolik, adalah sekitar $120 \mathrm{mmHg}$. Pada titik terendah setiap pulsasi, yang disebut tekanan diastolik, nilainya sekitar 80 mmHg. Perbedaan nilai antara kedua 
tekanan ini sekitar $40 \mathrm{mmHg}$, yang disebut tekanan nadi. ${ }^{5}$

Dua faktor utama yang memengaruhi tekanan nadi :

(1) curah isi sekuncup dari jantung, dan

(2) komplians (distensibilitas total) dari percabangan arteri.

Tekanan nadi pada orang lanjut usia kadang-kadang meningkat sampai dua kali nilai normal, karena arteri menjadi lebih kaku akibat arteriosklerosis dan karenanya, arteri relatif tidak lentur. ${ }^{5}$

Beberapa pusat yang mengawasi dan mengatur perubahan tekanan darah, yaitu : ${ }^{6}$

1. Sistem saraf yang terdiri dari pusatpusat yang terdapat di batang otak, misalnya pusat vasomotor dan diluar susunan syaraf pusat, misalnya baroreseptor dan kemoreseptor.

2. Sistem humoral atau kimia yang dapat berlangsung lokal atau sistemik, misalnya reninangiotensin, vasopressin, epinefrin, norepinefrin, asetilkolin, serotonin, adenosin dan kalsium, magnesium, hidrogen, kalium, dan sebagainya.

3. Sistem hemodinamik yang lebih banyak dipengaruhi oleh volume darah, susunan kapiler, serta perubahan tekanan osmotik dan hidrostatik di bagian dalam dan di luar sistem vaskuler.

Dalam lingkungan masyarakat modern, baik tekanan darah sistolik maupun diastolik cenderung meninggi sampai kirakira usia 60 tahun. Setelah usia tersebut, tekanan darah sistolik dapat terus naik, sedangkan tekanan diastolik cenderung tetap atau menurun. Sebaliknya, dalam lingkungan masyarakat desa, baik tekanan darah sistolik maupun diastolik tidak meningkat dengan bertambahnya usia. Hal ini telah diperkirakan karena asupan jumlah natrium yang lebih rendah ( $<60$ meq per hari) pada populasi tersebut. ${ }^{7}$

Tekanan darah bisa bervariasi bahkan pada orang yang sama misalnya pada saat berolahraga. ${ }^{9}$ Olahraga akan menyebabkan tekanan darah meningkat untuk waktu yang singkat dan akan kembali normal ketika berhenti berolahraga. ${ }^{10}$ Tekanan darah dalam satu hari juga berbeda yaitu pada waktu pagi hari tekanan darah lebih tinggi dibandingkan saat tidur malam hari karena adanya perbedaan tekanan darah sistolik selama 2 jam pertama setelah bangun tidur dikurangi tekanan darah sistolik terendah dalam sehari. ${ }^{11}$ Selain itu, faktor yang dapat mempengaruhi perbedaan tekanan pada pembuluh darah adalah posisi tubuh dimana perubahan tekanan darah pada posisi tubuh dipengaruhi oleh faktor gravitasi. $^{12}$

\section{METODE PENELITIAN}

Penelitian ini merupakan penelitian observasional analitik dengan menggunakan rancangan potong lintang Dilakukan pada bulan Juni-Juli 2015 di Kompleks Kantor Bupati Minahasa Utara, Airmadidi dengan sampel berjumlah 42 orang yang memenuhi kriteria sebagai Pegawai Negeri Sipil yang mengabdi untuk Kabupaten Minahasa Utara.

Pada penelitian ini, variabel bebas ialah posisi duduk dan posisi berdiri sedangkan variabel terikat adalah tekanan darah. Prosedur penelitian yaitu dilakukan pemilihan Pegawai Negeri Sipil yang akan dijadikan sampel kemudian memberikan penjelasan mengenai cara dan jalannya penelitian. Pegawai Negeri Sipil yang bersedia untuk menjadi responden maka diminta untuk menandatangani formulir persetujuan informed consent.

Alat dan bahan yang digunakan untuk pemeriksaan antara lain sfigmomanometer air raksa, stetoskop, dan alat tulis menulis. Teknis analisis data yang digunakan berupa analisis univariat dan bivariat. Analisis univariat dilakukan untuk melihat distribusi frekuensi dari variabel dependent dan variabel independent. Analisis bivariat dilakukan untuk mengetahui hasil pengukuran tekanan darah antara posisi duduk dan posisi berdiri. Analisis bivariat dianalisis dengan menggunakan Wilcoxon Signed Ranks Test. 


\section{HASIL PENELITIAN}

Tabel 1. Distribusi karakteristik dari responden berdasarkan usia

\begin{tabular}{ccc}
\hline Usia (tahun) & Frekuensi & \\
\cline { 1 - 2 }$\ldots \leq 30$ & 5 & \\
$31-40$ & 16 & \\
$41-50$ & 14 & $\ldots, \ldots$ \\
$51 \leq \ldots$ & 7 & 16,67 \\
\hline Jumlah & 42 & 100,0 \\
\hline
\end{tabular}

Tabel 2. Distribusi karakteristik responden berdasarkan jenis kelamin

\begin{tabular}{ccc}
\hline Jenis Kelamin & Frekuensi & (\%) \\
\hline Laki-laki & 22 & 52,38 \\
Perempuan & 20 & 47,62 \\
\hline Jumlah & 42 & 100,0 \\
\hline
\end{tabular}

Tabel 3. Hasil statistik tekanan darah sistolik pada posisi duduk dan posisi berdiri dalam $\mathrm{mmHg}$

\begin{tabular}{ccc}
\hline $\begin{array}{c}\text { Tekanan Darah } \\
\text { Sistolik }\end{array}$ & $\begin{array}{c}\text { Posisi } \\
\text { Duduk }\end{array}$ & $\begin{array}{c}\text { Posisi } \\
\text { Berdiri }\end{array}$ \\
\hline Rata-rata & 117,9841 & 124,7302 \\
Standar Deviasi & 12,5877 & 11,9546 \\
Nilai Minimum & 92 & 105,33 \\
Nilai Maximum & 160 & 165,33 \\
\hline
\end{tabular}

Tabel 4. Hasil statistik tekanan darah diastolik pada posisi duduk dan posisi berdiri dalam mmHg.

\begin{tabular}{ccc}
\hline $\begin{array}{c}\text { Tekanan Darah } \\
\text { Diastolik }\end{array}$ & $\begin{array}{c}\text { Posisi } \\
\text { Duduk }\end{array}$ & $\begin{array}{c}\text { Posisi } \\
\text { Berdiri }\end{array}$ \\
\hline Rata-rata & 79,2698 & 87,5238 \\
Standar Deviasi & 9,0656 & 8,6639 \\
Nilai Minimum & 64,0 & 70,67 \\
Nilai Maximum & 102,67 & 110,67 \\
\hline
\end{tabular}

Tabel 5. Analisis Wilcoxon Signed Ranks Test terhadap tekanan darah pada posisi duduk dan posisi berdiri.

\begin{tabular}{lccc}
\hline Parameter & \multicolumn{2}{c}{$\mathrm{Z}$} & \multicolumn{2}{c}{$\mathrm{P}$} \\
\hline Tekanan & Darah & $-5,513$ &, $000^{*}$ \\
$\begin{array}{l}\text { Sistolik } \\
\text { Tekanan }\end{array}$ & Darah & $-5,648$ &, $000^{*}$ \\
$\begin{array}{l}\text { Diastolik } \\
\text { *bermakna secara statistik }\end{array}$ &
\end{tabular}

\section{BAHASAN}

Berdasarkan hasil penelitian, pada analisa univariat didapatkan hasil bahwa subyek penelitian terbagi menjadi 4 kelompok usia yakni usia dibawah atau sampai dengan 30 tahun, 31-40 tahun, 4150 tahun dan 51-60 tahun. Kelompok usia terbanyak terdapat pada usia antara 31-60 tahun dengan jumlah 16 orang (38,09\%), sedangkan kelompok usia paling sedikit adalah dibawah atau sampai dengan 30 tahun dengan jumlah 5 orang (11,91\%). Untuk jenis kelamin, Subyek terbanyak yaitu laki=laki dengan jumlah 22 orang (52,38 \%) sedangkan perempuan 20 orang $(47,62 \%)$.

Pengukuran tekanan darah sistolik pada posisi duduk menunjukkan tekanan darah terendah $92 \mathrm{mmHg}$ dan tertinggi 160 mmHg dengan nilai rata-rata $117,9841 \pm 12,5877 \mathrm{mmHg}$, sedangkan pada posisi berdiri menunjukkan tekanan darah terendah 105,33 $\mathrm{mmHg}$ dan tertinggi $165,33 \mathrm{mmHg}$ dengan nilai rata-rata $124,7302 \pm 11,9546 \mathrm{mmHg}$. Hasil tersebut menunjukkan terdapat perbedaan nilai tekanan darah sistolik pada posisi duduk dan posisi berdiri yang mana perubahan yang terjadi adalah peningkatan tekanan darah sistolik dari posisi duduk ke posisi berdiri.

Pengukuran tekanan darah diastolik pada posisi duduk menunjukkan tekanan darah terendah $64 \mathrm{mmHg}$ dan tertinggi $102,67 \mathrm{mmHg}$ dengan nilai rata-rata 79,2698 $\pm 9,0656 \mathrm{mmHg}$, sedangkan untuk posisi berdiri menunjukkan tekanan darah terendah 70,67 $\mathrm{mmHg}$ dan tertinggi 110,67 $\mathrm{mmHg}$ dengan nilai rata-rata 
87,5238 $\pm 8,6639 \mathrm{mmHg}$. Hasil tersebut menunjukkan perbedaan nilai tekanan darah diastolik pada posisi duduk dan posisi berdiri dimana perubahan yang terjadi ialah peningkatan tekanan darah diastolik dari posisi duduk ke posisi berdiri.

Berdasarkan hasil analisa bivariat dengan menggunakan Wilcoxon Signed Ranks Test pada penelitian ini didapatkan perbedaan hasil pengukuran tekanan darah antara posisi duduk dan posisi berdiri menunjukkan terdapat perbedaan yang signifikan dengan nilai $\mathrm{p}=0,000<\alpha=0,05$. Hal ini tidak sejalan dengan penelitianpenelitian yang sebelumnya baik oleh Song MR dan Lee YS di Korea, ataupun Epser cs di Turki serta Muhamad Akrim Amirudin di Manado, yang menunjukkan penurunan tekanan darah baik sistolik maupun diastoliknya. Perbedaan hasil penelitian ini kemungkinan diakibatkan oleh faktor usia karena kelompok subyek yang diteliti oleh mereka adalah kelompok mahasiswa muda yang usianya berkisar antara 20-22 tahun yang masih berpotensi bebas dari risiko hipertensi primer, sementara pada penelitian ini subyek yang diteliti memiliki range usia yang luas dari 22-58 tahun, dengan kondisi faal tubuh yang multi kompleks. Sementara kemungkinan faktor lainnya adalah faktor lingkungan saat pengukuran dilakukan, yang mana pengukuran tekanan darah sampel dilakukan di dalam kantor mereka yang berada di lantai 2 atau 3 di Kompleks Kantor Bupati Minahasa Utara. Di sisi lain, penelitian ini sejalan dengan sebagian hasil penelitian Andrea Roatti yang berkesimpulan bahwa tekanan darah diastolik pada posisi berdiri lebih tinggi dari pada tekanan diastolik darah pada posisi duduk. $^{13}$

Apabila seseorang dalam posisi berdiri, tekanan intravaskular di semua tempat menjadi sama dengan tekanan yang dihasilkan oleh kontraksi jantung di tambah tekanan tambahan sama dengan berat kolom darah dari jantung ke titik pengukuran. Pada rata-rata orang dewasa, misalnya, berat kolom darah yang membentang dari jantung ke kaik adalah 80
mmHg. Pada kapiler kaki, tekanan meningkat dari 25 (tekanan kapiler rata-rata yang dihasilkan dari kontraksi jantung) menjadi $105 \mathrm{mmHg}$, peningkatan 80 mmHg ini disebabkan oleh berat kolom darah. Teori tekanan hidrostatik menyatakan bahwa tekanan pada permukaan air sama dengan tekanan atmosfer pada semua bagian air yang terpapar oleh udara, namun tekanan meningkat $1 \mathrm{mmHg}$ untuk setiap penurunan 13,6 mmHg dari permukaan. Tekanan hidrostatik berperan pada sistem kardiovaskular karena adanya beban darah pada vena yang dapat dinyatakan dalam rumus $\rho$ $\mathrm{x} \mathrm{g}$ x h yang mana $\rho$ adalah densitas darah $\left(1,05 \mathrm{~g} / \mathrm{cm}^{2}\right)$, g adalah percepatan gravitasi $\left(980 \mathrm{~cm} / \mathrm{s}^{2}\right)$ dan $\mathrm{h}$ adalah tinggi dari permukaan $(\mathrm{cm}){ }^{14,15}$

Peningkatan tekanan akibat gravitasi mempengaruhi volume sirkulasi darah efektif melalui beberapa cara. Pertama, peningkatan tekanan hidrostatik yang terjadi di kaki ketika seseorang berdiri akan mendorong keluar dinding vena sehingga menyebabkan distensi. Hasilnya adalah mengumpulnya darah di pembuluh vena. Sebagian darah yang berasal dari kapiler akan masuk ke pembuluh vena yang melebar daripada kembali ke jantung. Dalam waktu yang sama, peningkatan tekanan kapiler yang disebabkan oleh gaya gravitasi menyebabkan peningkatan filtrasi cairan dari kapiler ke ruang interstitial. Akibat mengumpulnya darah di vena dan peningkatan filtrasi kapiler, akan mengurangi volume sirikulasi darah efektif. Penurunan aliran balik vena menyebabkan penurunan sementara volume akhir diastolik. Hal ini akan mengurangi stroke volume, dan pada akhirnya mengurangi curah jantung serta penurunan tekanan darah. Pada posisi duduk, pusat gravitasi berada pada bagian anterior ischia dan sekitar $25 \%$ berat badan ditransmisikan ke bawah melalui ekstremitas bawah sehingga anggota tubuh dalam keadaan rileks. ${ }^{14,15}$

Naiknya tekanan darah pada posisi berdiri yang sejalan dengan penelitian ini, disinggung dalam suatu laporan praktikum yang menyebutkan bahwa secara teoritis 
tekanan darah pada posisi berdiri lebih tinggi dari pada posisi duduk yang diakibatkan karena pada posisi berdiri tekanan darah dipengaruhi oleh gaya gravitasi dan otot yang sedang berkontraksi ${ }^{16}$, akan tetapi laporan itu tidak menyebutkan referensi rinci dari teori tersebut.

Pada penelitian ini pengukuran tekanan darah antara posisi duduk dan posisi berdiri diperoleh perbedaan yang signifikan dengan nilai $p=0,000<\alpha=0,05$, yang mana perubahan yang terjadi ialah kenaikan tekanan darah dari posisi duduk ke posisi berdiri dengan selisih rata-rata masingmasing yakni untuk tekanan darah sistolik sebesar -6,7461 mmHg dan untuk tekanan darah diastolik sebesar $-8,2540 \mathrm{mmHg}$ (tanda negatif menunjukkan bahwa tekanan darah pada posisi berdiri lebih tinggi dari pada posisi duduk).

\section{SIMPULAN}

Dari hasil penelitian dapat disimpulkan bahwa pengukuran tekanan darah sistolik maupun diastolik antara posisi duduk dan posisi berdiri berbeda bermakna dimana terjadi peningkatan tekanan darah sistolik maupun diastolik dari posisi duduk ke posisi berdiri.

\section{SARAN}

1. Diperlukan suatu penelitian lanjut pengukuran tekanan darah pada berbagai posisi dan perbedaan waktu istirahat sebelum melakukan pengukuran tekanan dari penelitian ini.

2. Dalam penelitian ini, pengukuran tekanan darah dilakukan pada Pegawai Negeri Sipil (PNS), sehingga diperlukan suatu penelitian lebih lanjut pengukuran tekanan darah pada subyek dari golongan profesi tertentu, seperti petani, buruh, pengacara, tentara, dan lain-lainnya dengan memperhatikan juga faktor usia subyek dan lingkungan tempat pengukuran dilakukan.

\section{DAFTAR PUSTAKA}

1. Eșer I, Khorshid L, Güneş YU, Demir Y. The effect of different body positions on blood pressure. J Clin Nurs Jan 2007;16(1):137-40.

2. Setiawan R, Sari F. Fisiologi Kardiovaskular. Jakarta: EGC, 2010; p. 26-35.

3. Sherwood L. Pembuluh Darah dan Tekanan Darah. Dalam: Yesdelita N, Editor. Fisiologi Manusia dari sel ke sistem. Edisi ke-6. Jakarta: EGC, 2011.

4. Aaronson PI, Ward, JPT. At a Glance Sistem Kardiovaskular Edisi Ketiga. Jakarta: Erlangga Medical Series, 2008.

5. Guyton AC, Hall JE. Buku Ajar Fisiologi Kedokteran Edisi 11. Rachman LY, et al, editor. Jakarta: EGC Medical Publisher, 2007.

6. Mas'ud I. Dasar-dasar Fisiologi Kardiovaskuler. Jakarta: EGC, 1996.

7. Frohlich ED. Hipertensi The Merck Manual Geriatrics Jilid I. Tangerang Selatan: Binarupa Aksara Publisher, 2013.

8. Armstrong RS. Nurses' knowledge of error in blood pressure measurement technique. Int $\mathrm{J}$ Nurs Pract. 2002;8(3):118-26.

9. Rebecca JS. High blood pressure. Juli 2012 [cited 2015 Sep 15]. Available From: http://health.cvs.com/

10.Blood Pressure Association. Healthy lifestyle and blood pressure. Juli 2008 [cited 2014 Sep 14]. Available from : http://www.bloodpressureuk.org/

11.Rahmani A, editor. Terapi hipertensi: program 8 minggu menurunkan tekanan darah tinggi dan mengurangi risiko serangan jantung dan stroke secara alami. 1 st ed. Bandung: Qanita, 2010; p. 54.

12.Barbeau TR. Cardiovascular physiology. Florence: Francis Marion University, 2004.

13.Amiruddin, MA et al, Analisa Hasil Pengukuran Tekanan Darah Antara Posisi Duduk dan Posisi Berdiri Pada Mahasiswa Semester VII (Tujuh) TA. 2014/2015 Fakultas Kedokteran Universitas Sam Ratulangi. Jurnal eBiomedik 2015;3(1).

14. Widmaier EP, Raff H, Strang KT. Vander's Human Physiology: The Mechanisms of Body Function. Edisi ke-12. Mc-Graww Hill, 2008.

15.Pan RCM, Benoit R, Girardier L. The 
Jurnal e-Biomedik (eBm), Volume 3, Nomor 3, September-Desember 2015

Role of Body Position and Gravity in the symptoms and treatment of various diseases. Muttenz: Swiss Medical Weekly, 2004.

16. Wardani E, Suriantika C, Kurniawan F, Raharditama A, Siagian K, Adlian R, Ardiansyah
A. Laporan
Kelompok Praktikum Anatomi Fisiologi Manusia Tekanan Darah Arteri pada Manusia, Kelompok IIC. Jakarta: Jurusan Farmasi Fakultas Farmasi dan Sains Universitas Muhammadiyah Prof. Dr. Hamka, 2013. 